\title{
JNVESTJGAACJÓN
}

\section{Enzyme-aided cold pressing of flaxseed (Linum usitatissimum L.): Enhancement in yield, quality and phenolics of the oil}

\author{
By F. Anwar ${ }^{1,2, \bigotimes}$, Z. Zreen ${ }^{2}$, B. Sultana ${ }^{2}$ and A. Jamil ${ }^{2}$ \\ ${ }^{1}$ Department of Chemistry, University of Sargodha, Sargodha-40100, Pakistan \\ ${ }^{2}$ Department of Chemistry and Biochemistry, University of Agriculture, Faisalabad-38040, Pakistan \\ Corresponding author: fqanwar@yahoo.com
}

\section{RESUMEN}

Prensado en frío de semillas de lino (Linum usitatissimum L.) con enzimas asistida: Mejora en el rendimiento, la calidad y los compuestos fenólicos del aceite

Se evalúa el efecto de diferentes preparaciones enzimáticas (Viscozyme L, Kemzyme y Feedzyme) sobre el rendimiento y propiedades fisicoquímicas y antioxidantes de aceites de lino prensados en frío. El rendimiento en aceite $(35,2-38,0 \%)$ de las semillas de lino prensadas en frío (ETCPF), y tratadas con enzimas, aunque menor que el rendimiento mediante Soxhlet (SEO), fue considerablemente mayor en comparación con el control $(32,5 \%)$, mientras que el contenido de proteína, fibra, y cenizas no se vieron afectados por el tratamiento enzimático. La mayoría de los parámetros físico-químicos tales como el índice de refracción, densidad, índice de yodo, el contenido de ácidos grasos libres, índice de saponificación, el color y el perfil de ácidos grasos no variaron significativamente entre el aceite ETCPF, SEO y el control. Curiosamente, el estado de oxidación en términos de peróxidos, $p$-anisidina, dienos y trienos conjugados, período de inducción (método Rancimat), así como puntuación sensorial del aceite ETCPF fueron superiores en comparación con el control. Una cantidad sensiblemente superior de tocoferoles $\left(350-400 \mathrm{mg} \mathrm{kg}^{-1}\right)$ se determinó en el aceite ETCPF, en relación con el control $\left(270 \mathrm{mg} \mathrm{kg}^{-1}\right)$, mostrando un aumento de 22,8 a $32,5 \%$ en la recuperación de los tocoferoles totales. Por otra parte, el aceite de ETCPF mostró mayor actividad antioxidante y fenoles totales y contenido de ácidos fenólicos individuales. Este estudio aboga por la extracción mediante presión en frío con enzima asistida como una alternativa viable al prensado en frío convencional para mejorar no sólo el rendimiento de extracción sino también la calidad de los componentes funcionales de alto valor como los de los aceites de linaza.

PALABRAS CLAVE: Ácidos fenólicos - Carbohidrasas - HPLC - Linolénico - Parámetros físico-químicos - Prensado en frío de aceite - Propiedades antioxidante - Tocoferoles - TPC.

\section{SUMMARY}

Enzyme-aided cold pressing of flaxseed (Linum usitatissimum L.): Enhancement in yield, quality and phenolics of the oil

The effect of different enzyme preparations (Viscozyme L, Kemzyme, and Feedzyme) on the yield and physicochemical and antioxidant properties of cold pressed flaxseed oil were assessed. The oil yield (35.2-38.0\%) from enzyme-treated cold pressed flaxseeds (ETCPF), although lower than Soxhlet extracted oil (SEO) yield, was considerably higher when compared with the control $(32.5 \%)$ while the contents of protein, fiber, and ash were unaffected by the enzymatic treatment. Most of the physicochemical parameters such as refractive index, density, iodine number, free fatty acid contents, saponification value, color and fatty acid profile did not vary significantly among the ETCPF oil, SEO and the control. Interestingly, the oxidation status in terms of peroxide value, para-anisidine value, conjugated dienes and triens and induction period (Rancimat method) as well as the sensory score of the ETCPF oil were superior compared with the control. An appreciably higher amount of tocopherols (350-400 mg kg-1) was determined in the ETCPF oil, compared to the control $\left(270 \mathrm{mg} \mathrm{kg}^{-1}\right)$, showing an increase of $22.8-32.5 \%$ in the recovery of total tocopherols. Moreover, ETCPF oil exhibited greater antioxidant activity as well as total phenolics and individual phenolic acid content. This study advocates the exploration of enzyme-assisted cold pressing as a viable alternative to conventional cold-pressing for improving not only the extraction yield but also the functional food quality of flaxseed-like high-value oils.

KEY-WORDS: Antioxidant Properties - Carbohydrases Cold pressed oil - HPLC - Linolenic acid - Phenolic acids Physicochemical-parameters - Tocopherols - TPC.

\section{INTRODUCTION}

Flaxseed (Linum usitatissimum L.), also known as linseed, is a multipurpose oil seed crop belonging to the family Linaceae. The cultivation of flaxseed dates back to the history and origin of human agriculture. It is assumed that the cultivation of flaxseed was started in Southern Mesopotamia and then its growth as an oil seed crop expanded from Europe to other regions such as Africa, Asia and North America. Worldwide, Canada is the largest producer and importer of flaxseed (Oomah, 2001).

Flaxseed, besides its traditional oleochemical uses, is currently gaining recognition as a functional food ingredient for the human diet due to its high nutritional and medicinal health functions (Oomah, 2001; Lei et al., 2003; Hussain et al., 2011; Anwar and Przybylski, 2012). The health benefits of 
flaxseed can be linked to the presence of highvalue components such as lignans, fiber, phenolics, and polyunsaturated fatty acids (Oomah, 2001; Tarpila et al., 2005; Hosseinian et al., 2006).

It has been revealed that the flaxseed coat has a considerable amount of lignans (Wiesenborn et al., 2003; Westcott and Muir, 2003). The potential benefits related to the consumption of lignans in the human diet are well documented (Westcott et al., 2003; Bylund et al., 2005). Lignan compounds can reduce the risk of prostate and breast cancers (Westcott and Muir, 2003; McCann et al., 2006). Flaxseed usually contains more than $40 \%$ oil (36-48\%) which is characterized by the presence of high amounts of polyunsaturated fatty acids (mainly $\mathrm{C} 18: 3$ and $\mathrm{C} 18: 2$ ) (Matthews et al., 2000; Riley et al., 2000; Oomah, 2001; Kouba, 2006). Polyunsaturated fatty acids provide protection to the body against cardiovascular diseases and certain cancers (Maillard et al., 2002; Schaefer, 2002). Flaxseed can be used to modify the lipid profile of different food and feed commodities thus offering health benefits to both animals as well as human beings (Matthews et al., 2000; Riley et al., 2000). Flaxseed oil is not only famous for its nutritional and health functions, but is also very useful for oleochemical purposes and is incorporated into cosmetic and paint formulations (Kouba, 2006; Hussain et al., 2011).

Traditional solvent extraction (SE), involving the use of organic solvents such as $n$-hexane or petroleum ether, is known as one of the most efficient and economically feasible means to extract oils from vegetable oilseeds and other oil bearing materials. However, there are some oil product quality, process safety and environmental issues associated with this conventional SE process (Latif et al., 2007; Latif and Anwar, 2009). During SE, the oil has to be exposed to an accelerated and drastic heat treatment which not only decreases the functional food quality of the oil extracted but can alter and reduce the nutritional value of the protein and essential amino acids in the oil seed residues obtained (Latif and Anwar, 2009; Latif and Anwar, 2011).

Currently, there is growing concern for the development of different techniques, for example, supercritical-fluid extraction (SCFE), microwave assisted extraction (MAE), as well as pressurized solvent extraction (PSE), which are applicable for the recovery and isolation of various natural components such as lipids, steroids, terpenoids, phenolics and essential oils from plant materials (Kaufmann and Christen, 2002; Gao et al., 2006). In this way, enzyme-assisted cold pressing and enzyme-assisted aqueous extraction have emerged as recent eco-friendly technological developments (Latif and Anwar, 2009; Latif and Anwar, 2011). The use of enzymes during oil seed extraction is reported to facilitate the degradation of seed cell walls thus improving the recovery (oil extraction yield) as well as the functional food and nutritive quality of the oil produced through this process (Ranalli et al., 2005; Latif et al., 2011). Cold pressing has been in use as a safer and affordable method for recovering oil from different seeds. The major drawback in this process is that it offers low oil extraction yields which can be further increased through the application of selected enzymes. Enzymatic-assisted cold pressing (EACP) is considered to be an environmentally safe alternative, offering improved oil recovery and oil quality (Latif et al., 2007; Latif and Anwar, 2009).

To the best of our understanding, no detailed investigation has been carried out with the aim of evaluating the effects of enzymatic treatment on the extraction yield and quality of oil derived from flaxseed via cold pressing. The present research work has the main objective of studying the effect of different enzyme preparations on the quality and antioxidant attributes of the oil produced by EACP. The physicochemical properties, fatty acids, tocopherols and antioxidant activity and individual phenolic compositions of the flaxseed oil obtained by EACP were evaluated and related with that of cold pressed oil (CPO)/control oil and HEO.

\section{EXPERIMENTAL}

\subsection{Materials}

Purified flaxseeds were provided by a local agricultural institute at Faisalabad, Pakistan. The chemicals/ reagents/ standards of tocopherols [DL$\alpha$-tocopherol, $(+)$ - $\delta$-tocopherol, $(+)-\gamma$-tocopherol], and fatty acid methyl esters (FAMEs) were from Merck (Darmstadt, Germany) and/or SigmaAldrich (Buchs, Switzerland). The following enzyme preparations with broad range activities were employed: Viscozyme L. (a multi-enzyme complex of carbohydrates having mainly cellulase, $\beta$-glucanase, arabanase, hemicellulase, and xylanase activities) from Novozymes Bagsvaerd (Denmark), Kemzyme (mainly with $\beta$-glucanase, $\alpha$-amylase, cellulase, hemicellulase, protease and xylanase activities) from Kemin Europa N.V., (Belgium) and Feedzyme (mainly having xylanase, $\beta$-glucanase, cellulase and hemicellulas as constituents) from Agil (UK).

\subsection{Oil extraction}

\subsubsection{Soxhlet extraction ( $n$-hexane extraction)}

Whole, clean flaxseeds were ground (80-mesh) with a coffee grinder and then subjected to conditioning $\left(80^{\circ} \mathrm{C}\right)$ for 20 minutes. Accurately weighed $(100 \mathrm{~g})$ ground seed material was placed in a Soxhlet extractor. The extractor was fitted with a condenser and a $0.5 \mathrm{~L}$ round bottomed flask. The extraction of oil was done in a water bath for six hours, using about $350 \mathrm{~mL} n$-hexane. After the extraction cycle was completed, the excess hexane was removed via distillation under vacuum using a rotary evaporator (Rikakikai Co. Ltd., Tokyo, Japan) at $45^{\circ} \mathrm{C}$. The oil recovered was preserved at $4{ }^{\circ} \mathrm{C}$ until used for further analyses (Latif et al., 2011). 


\subsubsection{Enzyme-assisted cold pressing (EACP)}

The ground flaxseed material (80-mesh) was subjected to conditioning $\left(\right.$ at $80^{\circ} \mathrm{C}$ ) for 20 minutes. The enzymatic treatment was carried out under predetermined and optimized experimental conditions. Briefly, the ground seed material was independently treated/incubated with each of the three enzyme preparations (Viscozyme L, Kemzyme, and Feedzyme) at a concentration of $2.0 \%$ (by seed weight) for $6 \mathrm{~h}\left(40^{\circ} \mathrm{C}\right)$ while retaining $50 \%$ moisture contents (Latif and Anwar, 2009). Then, the enzyme was inactivated and the moisture level readjusted (as high as $3-4 \%$ by seed weight) by drying the enzymetreated material in an oven (VOC-300 SD; EYELA, Tokyo, Japan) at $100^{\circ} \mathrm{C}$ prior to pressing (Zuniga et al., 2001; Latif et al., 2007). A manual Laboratory Hydraulic Press (Carver Press, USA) was used for pressing and oil recovery purposes. The pressing was continued for $20 \mathrm{~min}$ with the pressure input exerted between 30.0-49.0 MPa (Moure et al., 2002). A control oil sample was also prepared by pressing the seed material under the specified conditions but without the enzyme treatment.

\subsection{Analysis of the oilseed residues}

The oilseed residues obtained after oil recovery were analyzed for ash, fiber and protein contents. Protein content was estimated according to the standard method of AOAC (1990) while fiber and ash contents were determined according to the ISO (1981) method 5983 and ISO (1977) method 749, respectively.

\subsection{Analysis of extracted oils}

\subsubsection{Physical and chemical parameters and sensory score}

Parameters such as iodine value, density, refractive index, saponification value, unsaponifiable matter, free FA and peroxide value of the oils, obtained through solvent extraction (SE), enzyme assisted cold pressing (EACP) and cold pressing (control) were analyzed according to AOCS standard procedures (AOCS, 1997). Oil color, in terms of yellow and red intensity, was measured with a Tintometer in a 1-in. cell while the refractive index was measured with a Refractometer (model RX-7000a; Atago Co., Ltd., Japan). For the spectrophotometric measurement of conjugated dienes and trienes, absorbance of the oil samples (dissolved in iso-octane) was taken at 232 and 270 $\mathrm{nm}$, and then specific extinctions were calculated according to the IUPAC standard method (IUPAC, 1987). A Hitachi, model U-2001 (Hitachi Instruments, Inc., Tokyo, Japan) spectrophotometer was used for the absorbance reading. An automated Rancimat apparatus (Metrohm, model 743), operating at a temperature of $120 \pm 0.1^{\circ} \mathrm{C}$ was employed to monitor the induction period (IP) or oxidative stability of the oils. The sensory score of the oils produced by different extraction methods was evaluated following the method described by Min (1983). A hedonic scale of 1-10, where 1 indicated the poorest and 10 the highest flavor quality, was used for sensory evaluation.

\subsubsection{Gas chromatographic FA analysis}

The oils produced by SE, EACP, and the control were converted into their fatty acid methyl esters (FAMEs) and then analyzed by a Shimadzu (Kyoto, Japan) gas chromatograph (model 17-A). A Supelco (Supelco Inc., Supelco Park Bellefonte, PA) SP2330 polar capillary column $(30 \mathrm{~m} \times 0.32 \mathrm{~mm}$; $0.2 \mu \mathrm{m}$ film thickness) was used for separation purposes. A mobile phase gas (nitrogen) was flushed through the column at a flow rate of $3.5 \mathrm{~mL}$ $\mathrm{min}^{-1}$. The initial temperature of the column was set at $180^{\circ} \mathrm{C}$ and increased by the rate of $5^{\circ} \mathrm{C} \mathrm{min}{ }^{-1}$ to a final temperature of $220^{\circ} \mathrm{C}$. The injector temperature was set at $230^{\circ} \mathrm{C}$ while the detector (FID) was set at $250^{\circ} \mathrm{C}$. The identification of targeted fatty acid compounds was based on matching their absolute and relative retention times against those of pure FAMEs standards. The quantitative measurement was made using a CSW data handling software while the composition of fatty acids (FA) in percent was reported as related to the total peak areas.

\subsubsection{Tocopherol contents}

Tocopherols $(\alpha, \gamma$ and $\delta$ ) were qualitatively and quantitatively analyzed using an HPLC (Sykam $\mathrm{GmbH}$, Kleinostheim, Germany) system fitted with an S-1122 pump, an S-3210 and UV/VIS diode array detector. Briefly, an accurately weighed amount of flaxseed oil was placed in a sample vial. The samples for HPLC analysis were prepared according to a method recommended in CPFAC (Wrolstad, 2003). Stock and working standard solutions of tocopherols were also prepared for calibration purposes. A 20$\mu \mathrm{L}$ sample solution was injected into a Hypersil ODS (C18) reverse phase column $(250 \times 4.6 \mathrm{~mm})$ fitted with a $\mathrm{C} 18$ guard column, and a three-solvent mixture comprising of methanol: acetonitrile: methylene chloride (50: 44: $6 \mathrm{v} / \mathrm{v}$, flow rate $1.5 \mathrm{~mL} \mathrm{~min}^{-1}$ ) was employed as the mobile phase. The detection of tocopherol isomers was made at $295 \mathrm{~nm}$. For identification purposes, the retention times (RT) of the unknown tocopherol compounds were compared with those of pure standards of tocopherols. An SRI Chromatointegrator (SRI instrument, Torrance, CA) was used for the calculation of the amounts of tocopherols after the construction of the standard calibration curve.

\subsection{Antioxidant activity}

\subsubsection{Extraction of antioxidant constituents}

The oil antioxidant components were recovered using $80 \%$ aqueous methanol as described earlier 
(Parry et al., 2005). Briefly, $1.0 \mathrm{~g}$ of oil was taken in a test tube and mixed with the extracting solvent (80:20 methanol:water $v / v)$. The sample mixture was vortexed followed by centrifugation $(6,000 \mathrm{rpm})$ for five minutes. The supernatant was collected carefully using a pasture pipette. The residue was re-extracted using the same procedure. The extractions were combined and then the pooled extracts were freed of solvent under nitrogen streaming. The recovered extracts were finally dissolved in the extracting solvent and preserved for further experimental use.

\subsubsection{Estimation of total phenolics /TP}

TP were determined colorimetrically as described earlier (Anwar et al., 2007) using FCR (Folin Ciocalteu reagent). For this test, $0.5 \mathrm{~mL}$ of diluted extract solution $(0.01 \mathrm{~g} / 1.0 \mathrm{~mL})$ were combined with FCR and $7.5 \mathrm{~mL}$ deionized water. The mixture was kept for ten minute at room temperature. To this mixture, $1.5 \mathrm{~mL}$ of sodium carbonate $(20 \% \mathrm{w} / \mathrm{v})$ were added and then the mixture was incubated at $40^{\circ} \mathrm{C}$ in a water bath for 20 minutes followed by cooling and absorbance reading at $755 \mathrm{~nm}$. The quantity of $T P$, calculated as GAE (gallic acid equivalent) mg $100 \mathrm{~g}^{-1}$ dry matter, was reported.

\subsubsection{DPPH radical scavenging and linoleic acid oxidation inhibition potential}

The antioxidant activity (AA) of the oil extracts (OE) produced was also assessed by determining 2, 2-diphenyl-1-picrylhydrazyl (DPPH) radical scavenging capacity according to the method described in a recent publication (Latif and Anwar, 2011). The AA of the OE was also evaluated by assessing the inhibition of linoleic acid peroxidation. The OE (50 mg), diluted in absolute ethanol $(4 \mathrm{~mL})$, was mixed with $0.025 \mathrm{~mL}$ of $\mathrm{C} 18: 2$ (linoleic acid) and $0.05 \mathrm{M}$ sodium phosphate buffer (4 mL, $\mathrm{pH} 7$ ). The sample mixture was incubated $\left(40^{\circ} \mathrm{C}\right)$ in an oven for 360 hours. The magnitude of linoleic acid oxidation was assessed using the thiocyanate method as described by Yen et al. (2000). A commonly used synthetic compound named BHT was used as a positive control for comparison of the percent inhibition data of the test samples (Latif and Anwar 2011).

\subsection{HPLC analysis of phenolic acids}

Analysis of the phenolic acids in the methanol soluble extracts of flaxseed oil was carried out using HPLC fitted with an S-1122 dual piston solvent delivery system and an S-3210 UV/VIS diode array detector (Sykam $\mathrm{GmbH}$, Kleinostheim, Germany) according to a previously described method (Siger et al., 2008). The separation of phenolic acids was carried out on a hypersil ODS (C18) reverse phase column $(250 \times 4.6 \mathrm{~mm}$,
Themohypersil GmbH, Germany). A mobile phase, consisting of a mixture of solvent $A$ and Solvent B (A: pure methanol, B: $2.5 \%$ glacial acetic acid aqueous solution), at a flow rate of $1.5 \mathrm{~mL} \mathrm{~min}{ }^{-1}$, was employed using a gradient mode of elution. The targeted phenolic acids were detected at 250 and $320 \mathrm{~nm}$ and further identified by matching their retention times (absolute and relative $\mathrm{RT}$ ) with those of phenolic standards (Sigma). An SRI Chromatointegrator (SRI instrument, Torrance, CA) was used to quantify their amounts using external standard calibration curves.

\subsection{Statistical analysis}

The data recorded for various parameters were statistically analyzed by computing averages and standard deviation values. The mean data was also tested to determine significant variations among extraction techniques through the application of one way ANOVA using Minitab 2000 version 13.2 statistical software at a $5 \%$ significance level (Steel et al., 1997).

\section{RESULTS AND DISCUSSION}

In this research, three different extraction protocols were employed for the recovery of oil from locally harvested flaxseed. The oil produced by each of the methods was analyzed thoroughly for various quality-oriented attributes. The results obtained were computed and compared among the different extraction methods. Data obtained for the analysis of various physicochemical and antioxidant properties of enzyme-assisted cold pressed oil (EACPO), hexane (solvent) extracted oil (HEO) and the control oil (CO) are given in Tables 1 to 7 .

The oil yield (35.2-38.0\%) from enzyme treated cold pressed flaxseed (Table 1), although significantly higher $(P<0.05)$ than that of the control $(32.5 \%)$, was noted to be lower than that recovered by the hexane extraction method $(42.6 \%)$. The amount of oil recovered was relatively higher $(38.0 \%)$ in Viscozyme-treated seeds, while the sample that was extracted after treatment with Feedzyme, yielded the least amount of oil $(35.2 \%)$. The improvement in oil yield as a function of enzymatic treatment during the cold pressing compared with the control can be associated with better solubilization of the flaxseed cell body wall that surrounds the lipid bodies, resulting in the liberating of a higher content of oil (Tzen and Huang 1992; Latif et al., 2007; Latif and Anwar, 2009). Such trends were also investigated by Soto et al. (2004) who reported a considerable increase in the extraction yield of borage oil due to enzyme-aided cold pressing. Similarly, during the enzymatic-assisted extraction of sesame seed, groundnut, sunflower, cottonseed, and hemp seed, an improvement in oil recoveries has been recorded by researchers (Singh et al. 1999; Latif et al., 2007; Latif and Anwar, 2009). The content of protein, in 
the range of $23.00-24.80 \%$, for the enzyme-treated oilseed, was quite close to that of the control and hexane-extracted oilseeds. The levels of fiber and ash determined for enzyme-treated seed samples, $17.99-18.50$ and 9.60 to $10.00 \%$, respectively, were also noted to be as good as for the control and hexane extracted oilseeds indicating no considerable variations in the data $(P>0.05)$ among the different extraction methods.

The results for the different quality related attributes of EACPO, HEO and the $\mathrm{CO}$ are presented in Table 2. Statistically $(P>0.05)$, there were no notable differences observed for iodine value (IV), density, refractive index, saponification number or unsaponifiable contents among the flaxseed oils of different methods, revealing that the extraction methods employed did not affect these properties. On the other hand, a higher value of unsaponifiable contents in HEO compared to $\mathrm{CO}$ and EACPO might have been in part due to the efficacy of hexane to extract some lipidrelated components such as sterols, pigments and hydrocarbons (Abdulkarim et al. 2005). Similarly, the magnitude of free fatty acids (the product of hydrolysis) was almost similar in HEO, EACPO and CO. The color of enzyme-produced flaxseed oils was established as slightly varied from those of the oils yielded by other extraction means.

The oxidation parameters of the oils obtained by the different methods are summarized in Table 3. It is evident from the data generated that the oxidation state, in terms of measurements as specific extinctions at 232 and $270 \mathrm{~nm}$, peroxide value, $p$-anisidine value and induction periods (Rancimate method) is better than $\mathrm{HEO}$ and $\mathrm{CO}$, which might be linked to the mild conditions used for oil extraction in this process as well as to the recovery of higher amounts of tocopherols with antioxidant potential (Latif and Anwar, 2009). The magnitude of specific extinctions related to wavelength at 232 and 270 $\mathrm{nm}$ can be used to assess the oxidation status of vegetable oils (Latif and Anwar, 2009).

Similarly, the levels of peroxide and paraanisidine values, which are indicative of the primary and secondary oxidation products of oils, are noted to be lower in the case of EACPO compared to HEO and $\mathrm{CO}$. This supports the fact that the enzymatic treatment of flaxseed, prior to cold pressing,

Table 1

Comparison of proximate composition of flaxseeds

\begin{tabular}{lccccc}
\hline \multirow{2}{*}{ Parameters (\%) } & \multirow{2}{*}{ SE } & \multicolumn{2}{c}{ Enzyme assisted cold pressing } & \multirow{2}{*}{ Control } \\
\cline { 3 - 5 } & & Viscozyme L & Feedzyme & Kemzyme & \\
\hline Oil content & $42.80 \pm 0.15^{\mathrm{a}}$ & $38.00 \pm \pm 0.10^{\mathrm{b}}$ & $35.20 \pm 0.20^{\mathrm{b}}$ & $36.50 \pm 0.18^{\mathrm{b}}$ & $32.50 \pm 0.20^{\mathrm{c}}$ \\
Protein content & $24.80 \pm 0.05^{\mathrm{a}}$ & $25.20 \pm 0.18^{\mathrm{a}}$ & $24.70 \pm 0.20^{\mathrm{a}}$ & $24.25 \pm 0.15^{\mathrm{a}}$ & $23.00 \pm 0.15^{\mathrm{a}}$ \\
Fiber content & $18.01 \pm 0.10^{\mathrm{a}}$ & $18.50 \pm 0.10^{\mathrm{a}}$ & $18.20 \pm 0.17^{\mathrm{a}}$ & $17.99 \pm 0.15^{\mathrm{a}}$ & $18.10 \pm 0.08^{\mathrm{a}}$ \\
Ash content & $9.80 \pm 0.06^{\mathrm{a}}$ & $9.70 \pm 0.07^{\mathrm{a}}$ & $9.60 \pm 0.05^{\mathrm{a}}$ & $10.00 \pm 0.06^{\mathrm{a}}$ & $9.50 \pm 0.07^{\mathrm{a}}$ \\
\hline
\end{tabular}

The data are means $\pm S D$, expressed as percentage (on dry seed weight basis) for three flaxseed samples for each enzyme treatment performed independently in triplicate $(n=3 \times 3)$. Mean values in the same row followed by the same superscript letters are not significantly different $(P>0.05)$.

SE: solvent extracted

Table 2

Comparison of physiochemical parameters of flaxseed oils produced by different techniques

\begin{tabular}{|c|c|c|c|c|c|}
\hline \multirow{2}{*}{ Parameters } & \multirow{2}{*}{ SEO } & \multicolumn{3}{|c|}{ Enzyme assisted cold pressed oil } & \multirow{2}{*}{ Control } \\
\hline & & Viscozyme L & Feedzyme & Kemzyme & \\
\hline Refractive index $\left(40^{\circ} \mathrm{C}\right)$ & $1.4723 \pm 0.002^{a}$ & $1.4722 \pm 0.001^{a}$ & $1.4723 \pm 0.002^{a}$ & $1.4722 \pm 0.002^{\mathrm{a}}$ & $1.4723 \pm 0.001^{a}$ \\
\hline Density, $24^{\circ} \mathrm{C}\left(\mathrm{mg} \mathrm{mL}^{-1}\right)$ & $0.921 \pm 0.04^{\mathrm{a}}$ & $0.925 \pm 0.03^{\mathrm{a}}$ & $0.925 \pm 0.02^{\mathrm{a}}$ & $0.924 \pm 0.05^{a}$ & $0.921 \pm 0.04^{\mathrm{a}}$ \\
\hline $\begin{array}{l}\text { Saponification value } \\
\left(\mathrm{mg} \mathrm{KOH} \mathrm{g}^{-1} \text { oil) }\right.\end{array}$ & $188.00 \pm 3.00^{\mathrm{a}}$ & $186.00 \pm 3.70^{a}$ & $184.80 \pm 2.50^{a b}$ & $186.00 \pm 3.00^{a}$ & $187.00 \pm 3.80^{\mathrm{a}}$ \\
\hline FFA content ( $\%$ as oleic acid) & $1.00 \pm 0.10^{\mathrm{a}}$ & $1.12 \pm 0.05^{c}$ & $1.10 \pm 0.08^{c}$ & $1.15 \pm 0.10^{c}$ & $1.00 \pm 0.10^{c}$ \\
\hline Unsaponifiable matter (\% w/w) & $1.60 \pm 0.04^{\mathrm{a}}$ & $1.31 \pm 0.02^{\mathrm{ab}}$ & $1.25 \pm 0.05^{\mathrm{c}}$ & $1.36 \pm 0.05^{\mathrm{ab}}$ & $1.40 \pm 0.03^{b}$ \\
\hline Panel test (sensory score) & $6.30 \pm 0.10^{a}$ & $8.10 \pm 0.21^{b}$ & $7.90 \pm 0.19^{b}$ & $7.70 \pm 0.18^{b}$ & $7.20 \pm 0.61^{c}$ \\
\hline lodine value (g | $100 \mathrm{~g}^{-1}$ oil) & $168.00 \pm 3.40^{\mathrm{a}}$ & $174.00 \pm 3.00^{\mathrm{a}}$ & $169.20 \pm 3.40^{\mathrm{a}}$ & $170.50 \pm 4.10^{\mathrm{a}}$ & $170.00 \pm 2.91^{\mathrm{a}}$ \\
\hline Color (1-in. Cell) Red units & $4.40 \pm 0.80^{\mathrm{a}}$ & $4.20 \pm 0.70^{\mathrm{a}}$ & $4.50 \pm 0.60^{\mathrm{a}}$ & $4.30 \pm 0.50^{a}$ & $4.20 \pm 0.60^{a}$ \\
\hline Yellow units & $70.00 \pm 1.70^{\mathrm{a}}$ & $60.00 \pm 1.50^{c}$ & $65.00 \pm 1.00^{b}$ & $60.00 \pm 1.25^{\mathrm{c}}$ & $65.00 \pm 1.50^{b}$ \\
\hline
\end{tabular}

The data are means \pm SD of three flaxseed oil samples for each enzyme treatment, analyzed independently in triplicate $(n=3 \times 3)$. Mean values in the same row followed by the same superscript letters are not significantly different $(P>0.05)$.

SEO: Soxhlet extracted oil 
Table 3

Comparison of oxidation state of flaxseed oils produced by different techniques

\begin{tabular}{lccccc}
\hline \multirow{2}{*}{ Parameters } & \multirow{2}{*}{ SEO } & \multicolumn{2}{c}{ Enzyme assisted cold pressed oil } & \multirow{2}{*}{ Control } \\
\cline { 3 - 5 } & & Viscozyme $L$ & Feedzyme & Kemzyme & \\
\hline Conjugated diene ${ }^{1 \%} 1 \mathrm{~cm}(\lambda 232)$ & $3.81 \pm 0.06^{\mathrm{a}}$ & $2.24 \pm 0.08^{\mathrm{ab}}$ & $2.71 \pm 0.07^{\mathrm{ab}}$ & $2.69 \pm 0.06^{\mathrm{c}}$ & $2.80 \pm 0.02^{\mathrm{b}}$ \\
Conjugated triene ${ }^{1 \%} 1 \mathrm{~cm}(\lambda 270)$ & $0.86 \pm 0.03^{\mathrm{a}}$ & $0.50 \pm 0.02^{\mathrm{c}}$ & $0.61 \pm 0.03^{\mathrm{bc}}$ & $0.58 \pm 0.05^{\mathrm{bc}}$ & $0.62 \pm 0.04^{\mathrm{c}}$ \\
Peroxide value $\left(\mathrm{meq} \mathrm{kg}^{-1}\right)$ & $3.34 \pm 0.05^{\mathrm{a}}$ & $1.90 \pm 0.04^{\mathrm{b}}$ & $2.25 \pm 0.06^{\mathrm{b}}$ & $2.19 \pm 0.10^{\mathrm{c}}$ & $2.35 \pm 0.07^{\mathrm{ab}}$ \\
p-Anisidine value & $4.83 \pm 0.04^{\mathrm{a}}$ & $2.98 \pm 0.10^{\mathrm{b}}$ & $3.80 \pm 0.05^{\mathrm{b}}$ & $3.49 \pm 0.09^{\mathrm{b}}$ & $3.75 \pm 0.15^{\mathrm{b}}$ \\
Induction period $(\mathrm{h})^{\star}$ & $1.00 \pm 0.10^{\mathrm{b}}$ & $1.44 \pm 0.08^{\mathrm{c}}$ & $1.25 \pm 0.07^{\mathrm{a}}$ & $1.30 \pm 0.10^{\mathrm{bc}}$ & $1.22 \pm 1.40^{\mathrm{b}}$ \\
\hline
\end{tabular}

The data are means \pm SD of three flaxseed oil samples for each enzyme treatment, analyzed independently in triplicate $(n=3 \times 3)$. Mean values in the same row followed by the same superscript letters are not significantly different $(P>0.05)$.

SEO: Soxhlet extracted oil

${ }^{*}$ Rancimat method

Table 4

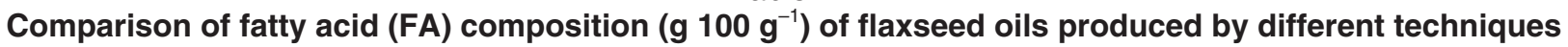

\begin{tabular}{cccccc}
\hline \multirow{2}{*}{ FA } & \multirow{2}{*}{ SEO } & \multicolumn{2}{c}{ Enzyme assisted cold pressed oil } & \multirow{2}{*}{ Control } \\
\cline { 2 - 5 } & & Viscozyme $\mathrm{N}$ & Feedzyme & Kemzyme & \\
\hline $16: 0$ & $8.00 \pm 0.30^{\mathrm{a}}$ & $7.30 \pm 0.04^{\mathrm{a}}$ & $7.39 \pm 0.05^{\mathrm{a}}$ & $7.39 \pm 0.03^{\mathrm{a}}$ & $7.18 \pm 0.05^{\mathrm{a}}$ \\
$18: 0$ & $4.70 \pm 1.90^{\mathrm{a}}$ & $4.25 \pm 1.80^{\mathrm{b}}$ & $4.20 \pm 1.60^{\mathrm{b}}$ & $4.15 \pm 1.80^{\mathrm{b}}$ & $4.16 \pm 1.70^{\mathrm{b}}$ \\
$18: 1$ & $19.39 \pm 0.57^{\mathrm{a}}$ & $18.39 \pm 0.54^{\mathrm{a}}$ & $18.38 \pm 0.50^{\mathrm{a}}$ & $18.39 \pm 0.35^{\mathrm{a}}$ & $19.00 \pm 0.75^{\mathrm{a}}$ \\
$18: 2$ & $16.03 \pm 0.75^{\mathrm{a}}$ & $16.54 \pm 0.71^{\mathrm{a}}$ & $16.03 \pm 0.61^{\mathrm{a}}$ & $16.04 \pm 0.41^{\mathrm{a}}$ & $15.90 \pm 0.39^{\mathrm{a}}$ \\
$18: 3$ & $52.20 \pm 1.20^{\mathrm{a}}$ & $53.14 \pm 1.50^{\mathrm{a}}$ & $54.00 \pm 1.45^{\mathrm{a}}$ & $53.93 \pm 1.60^{\mathrm{a}}$ & $54.00 \pm 1.80^{\mathrm{a}}$ \\
\hline
\end{tabular}

The data are means \pm SD of three flaxseed oil samples for each enzyme treatment, analyzed independently in triplicate $(n=3 \times 3)$. Mean values in the same row followed by the same superscript letters are not significantly different $(P>0.05)$.

SEO: Soxhlet extracted oil

positively affects the oxidation parameters of the oils. The conventional vegetable oilseed extraction process, involving the use of hexane as extracting solvent, is performed by means of a Soxhelt apparatus under an accelerated operational temperature that can negatively affect the oxidation state of oils thus leading to the development of rancid, off-odors, resulting in an oil of poor quality (Latif et al., 2007, Latif and Anwar, 2009).

The induction period predicts the oxidative stability, to the extent of which the oil is stable and resistant to oxidation when subjected to heating under accelerated temperature conditions. The induction periods of the oils were also notably increased as a result of enzymatic treatment with a magnitude of 1.25-1.44 $\mathrm{h}$ for enzyme produced oil as compared to $1.00 \mathrm{~h}$ for Soxhlet extracted oil and $1.22 \mathrm{~h}$ for the control oil. This enhancement in the induction period in the case of enzymatic extraction can be correlated to relatively higher amounts of antioxidant tocopherols recovered in the subsequent oil (Table 5). Similar increases in the induction periods of several oils such as olive oil (Ranalli and De Mattia, 1997), hemp seed oil (Latif and Anwar, 2009) and cottonseed oil (Latif et al., 2007) have already been reported in the literature.

The fatty acid profile of the tested flaxseed oils as analyzed by GLC is presented in Table 4. Apparently, there were no considerable variations observed in the composition or contents of the fatty acids of the oils produced by either of the three extraction methods. The fatty acid composition related results of our present investigations reveal no significant impact of enzymatic treatment, and can be supported by the findings of Abdulkarim et al. (2005), who also revealed non-significant qualitative or quantitative differences in the composition of fatty acids among enzyme-, solventextracted and the control Moringa oleifera oils. In line with the present study, Latif et al., (2007) and Latif and Anwar (2009) determined that there were no considerable changes in the composition of fatty acids during the cold pressing of enzyme treated cottonseed oil and hemp seed oils.

As expected, linolenic acid (C18:3 $n$-3) was determined to be the major fatty acid compound followed by linoleic acid (C18:2), oleic acid and palmitic acid, along with small traces of stearic acid in the flaxseed oils prepared by either the enzymatic method, Soxhelt method or cold pressing. A major contribution of flaxseed oil as a highly nutritious and medicinal health food among other oils is due to the presence of exceptionally high contents of linolenic acid. This oil is very rich in essential fatty acids namely C18:3 and C18:2 which together constitute more than $75 \%$ of the total fatty acids. Despite its highly nutritious value and medicinal health functions, this oil is more prone to oxidation because of the occurrence of high amounts of polyunsaturated fats, and thus is not recommended 
for deep frying or baking; although, like other unsaturated oils, it can be used under mild heat treatment conditions without a loss in nutritional benefits (Latif and Anwar, 2009; Daun et al., 2003).

Table 5 shows the composition of tocopherols analyzed in the tested flaxseed oils. The levels of $\alpha-, \gamma-$ and $\delta$-tocopherols in the EACPO oil were 3.99-5.74, 335-382 and 9.00-12.05 $\mathrm{mg} \mathrm{kg}^{-1}$, respectively. The contents of the major tocopherol, $\gamma$, as well as the total tocopherols of the enzymeextracted flaxseed oil (350.7-365.7 $\mathrm{mg} \mathrm{kg}^{-1}$ ) are considerably higher than those of hexane extracted oil $\left(228.0 \mathrm{mg} \mathrm{kg}^{-1}\right.$ ) and cold pressed or control oil $\left(270.0 \mathrm{mg} \mathrm{kg}^{-1}\right.$ ) indicating that enzyme treatment facilitates greater recovery of these antioxidant components into the yielded oil due to effective hydrolysis and breakdown of the seed cell wall. Various previous studies also reported higher recoveries of tocopherols due to enzymatic treatment offering better quality oils (Ranalli et al., 2005; Latif et al., 2007, Latif and Anwar, 2009).

Enzyme extracted flaxseed oil exhibited superior antioxidant activity, in terms of contents of total phenolics (TP), inhibition (percent) of linoleic (C18:2) peroxidation and DPPH radical scavenging potential when compared with the cold pressed, (control) and SEO (Table 6). It can be seen that phenolic compounds in the enzyme-produced oil are quite higher $(p<0.05)$ as compared to the $\mathrm{CO}$ and SEO. This improvement in the recovery of phenolics (8.61-10.50 mg GAE $100 \mathrm{~g}^{-1}$ ) recorded for the enzyme-aided method may be related to the decreased binding of these compounds with the seed polysaccharides resulting in greater partitioning and recovery into the oily phase (Ranalli et al., 2005). In accordance with TPC, the level of

Table 5

Comparison of tocopherol contents $(\mathrm{mg} / \mathrm{kg})$ of flaxseed oils produced by different techniques

\begin{tabular}{cccccc}
\hline \multirow{2}{*}{ Tocopherol } & \multirow{2}{*}{ SEO } & \multicolumn{2}{c}{ Enzyme assisted cold pressed oil } & \multirow{2}{*}{ Control } \\
\cline { 3 - 5 } & & Viscozyme $\mathbf{E}$ & Feedzyme & \multicolumn{1}{c}{ Kemzyme } & \\
\hline$\alpha$-tocopherol & $2.85 \pm 0.10^{\mathrm{c}}$ & $5.74 \pm 0.30^{\mathrm{a}}$ & $4.63 \pm 0.20^{\mathrm{ab}}$ & $3.99 \pm 0.20^{\mathrm{ab}}$ & $4.20 \pm 0.70^{\mathrm{ab}}$ \\
$\gamma$-tocopherol & $217.7 \pm 12.0^{\mathrm{d}}$ & $382.0 \pm 10.6^{\mathrm{a}}$ & $335.0 \pm 17.5^{\mathrm{c}}$ & $352.0 \pm 13.0^{\mathrm{b}}$ & $256.5 \pm 15.0^{\mathrm{ab}}$ \\
$\delta$-tocopherol & $8.20 \pm 0.20^{\mathrm{c}}$ & $12.05 \pm 0.80^{\mathrm{a}}$ & $10.06 \pm 0.90^{\mathrm{a}}$ & $9.00 \pm 0.40^{\mathrm{a}}$ & $8.63 \pm 4.10^{\mathrm{b}}$ \\
Total & $228.8^{\mathrm{d}}$ & $400.0^{\mathrm{a}}$ & $350.7^{\mathrm{b}}$ & $365.7^{\mathrm{c}}$ & $270.0^{\mathrm{cd}}$ \\
\hline
\end{tabular}

The data are means \pm SD of three flaxseed oil samples for each enzyme treatment, analyzed independently in triplicate $(n=3 \times 3)$. Mean values in the same row followed by the same superscript letters are not significantly different $(P>0.05)$.

SEO: Soxhlet extracted oil

Table 6

Antioxidant activity of flaxseed oil produced by different techniques

\begin{tabular}{lccccc}
\hline \multirow{2}{*}{ Parameters } & \multirow{2}{*}{ SEO } & \multicolumn{4}{c}{ Enzyme assisted cold pressed oil } \\
\cline { 2 - 5 } & & Viscozyme $\mathrm{L}$ & \multicolumn{1}{c}{ Feedzyme } & \multicolumn{1}{c}{ Kemzyme } & Control \\
\hline TPC (mg GAE/100 g) & $5.20 \pm 0.30^{\mathrm{c}}$ & $10.50 \pm 0.20^{\mathrm{a}}$ & $9.70 \pm 0.30^{\mathrm{a}}$ & $8.61 \pm 0.20^{\mathrm{a}}$ & $6.21 \pm 0.10^{\mathrm{bc}}$ \\
DPPH· Scavenging (\%) & $33.21 \pm 0.34^{\mathrm{a}}$ & $50.03 \pm 0.45^{\mathrm{a}}$ & $45.30 \pm 0.36^{\mathrm{bc}}$ & $43.01 \pm 0.93^{\mathrm{c}}$ & $35.20 \pm 0.63^{\mathrm{b}}$ \\
Inhibition of linoleic acid & $35.61 \pm 0.58^{\mathrm{c}}$ & $60.80 \pm 1.80^{\mathrm{ab}}$ & $53.70 \pm 1.20^{\mathrm{a}}$ & $47.22 \pm 1.50^{\mathrm{a}}$ & $38.00 \pm 0.48^{\mathrm{ab}}$ \\
peroxidation (\%) & & & & &
\end{tabular}

The data are mean \pm SD of three flaxseed oil samples for each enzyme treatment, analyzed independently in triplicate $(n=3 \times 3)$. Mean values in the same row followed by the same superscript letters are not significantly different $(P>0.05)$.

SEO: Soxhlet extracted oil

Table 7

Comparison of phenolic acids $\left(\mu \mathrm{g} 100 \mathrm{~g}^{-1}\right)$ of flaxseed oils

\begin{tabular}{|c|c|c|c|c|c|}
\hline \multirow{2}{*}{ Phenolic acids } & \multirow{2}{*}{ SEO } & \multicolumn{3}{|c|}{ Enzyme assisted cold pressed oil } & \multirow[b]{2}{*}{ Control } \\
\hline & & Viscozyme L & Feedzyme & Kemzyme & \\
\hline$p$-hydroxy benzoic acid & $1.21 \pm 0.15^{\mathrm{c}}$ & $3.20 \pm 0.20^{a}$ & $2.95 \pm 0.18^{b c}$ & $2.54 \pm 0.10^{b}$ & $2.34 \pm 0.15^{b}$ \\
\hline Vanillic acid & $0.67 \pm 0.06^{b}$ & $1.00 \pm 0.15^{a}$ & $0.85 \pm 0.07^{a}$ & $0.75 \pm 0.10^{a}$ & $0.89 \pm 0.12^{a}$ \\
\hline Caffeic acid & nd & nd & nd & nd & nd \\
\hline Ferulic acid & $0.45 \pm 0.08^{b}$ & $0.95 \pm 0.12^{a}$ & $0.78 \pm 0.12^{a}$ & $0.63 \pm 0.13^{a}$ & $0.57 \pm 0.09^{a}$ \\
\hline
\end{tabular}

The data are mean \pm SD of three flaxseed oil samples for each enzyme treatment, analyzed independently in triplicate $(n=3 \times 3)$. Mean values in the same row followed by the same superscript letters are not significantly different $(P>0.05)$.

SEO: Soxhlet extracted oil

nd: not detected. 
DPPH scavenging (43.01-50.03\%) as well as the inhibition of linoleic acid oxidation (47.22-60.80\%) for the enzyme-treated cold pressed flaxseed oil were notably higher than the SEO and CO thus supporting a greater recovery of antioxidant compounds as a result of enzymatic treatment.

Though no earlier literature is available regarding the evaluation of the antioxidant characteristics of flaxseed oil obtained via the application of enzymes prior to cold-pressing, previous works on some oils such as olive, hemp seed and cotton seed indicate that an enzymatic pretreatment during extraction considerably improves the recovery of highvalue minor components such as phenolics, and tocopherols and contribute antioxidant attributes to the oils (Ranalli et al., 2005; Latif and Anwar, 2009; Latif et al., 2007).

In Table 7, the composition of oil phenolic acids as analyzed by HPLC is given. The major phenolic acids in flaxseed oils determined were

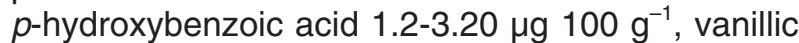
acid $0.6-100 \mu \mathrm{g} 100 \mathrm{~g}^{-1}$ and ferulic acid $0.45-$ $0.95 \mu \mathrm{g} 100 \mathrm{~g}^{-1}$. The contents of these phenolic compounds were higher in enzyme extracted flaxseed oil than SEO and CO. The levels of oil phenolic acids determined in the current study were in close agreement with the finding of Siger et al., (2008) who investigated phenolics in several cold pressed vegetable oils. Somewhat similar results as in our present study have also been reported for flaxseed phenolics as analyzed by Herchi et al., (2011) using HPLC-TOF-MS. Other studies support the fact that several vegetable oils contain considerable amounts of phenolic acids (Siger et al., 2008).

\section{CONCLUSION}

From the data presented in this study it could be claimed that that an enzymatic treatment has considerably improved the oil extraction yield from flaxseed in addition to improving oxidation state as well as the concentration of antioxidant phenolic components and tocopherols in the oils produced, without altering the actual composition of fatty acids. This study advocates that enzyme-assisted cold pressing can be explored as a viable alternative to conventional cold-pressing for improving not only the extraction yield but also the nutritive and functional food quality of flaxseed-like high-value oils. A detailed analysis of other bioactives of enzyme extracted flaxseed oil is needed in order to explore specific functional food or nutraceutical applications.

\section{ACKNOWLEDGEMENT}

The authors greatly acknowledge the Higher Education Commission (HEC) of Pakistan for providing a financial grant through project No.20-1344/ R\&D/09/2290, entitled "Exploration of Microwave-
Enzyme Assisted Method for Extraction of Seed Oils" to accomplish this research work.

\section{REFERENCES}

Abdulkarim SM, Long K, Lai OM, Muhammad SKS, Ghazali HM. 2005. Some physico-chemical properties of Moringa oleifera seed oil extracted using solvent and aqueous enzymatic methods. Food Chem. 93, 253-263.

American Oil Chemists Society (AOCS). 1997. Official and Recommended Practices of the American Oil Chemists Society, 5th edn., AOCS Press, Champaign, Illinois, USA.

Association of Official Analytical Chemists (AOAC). 1990. Official Methods of Analysis of the Association of Official Analytical Chemists, 15th edition, AOAC Inc., Virginia.

Anwar F, Latif S, Przybylski R, Sultana B, Ashraf M. 2007. Chemical composition and antioxidant activity of seeds of different cultivars of mungbean. J. Food Sci. 72, S503-S510.

Anwar F., Przybylski R. 2012. Effect of solvents extraction on total phenolics and antioxidant activity of extracts from flaxseed (Linum usitatissimum L.). Acta Sci. Pol. Technol. Aliment. 11, 293-301.

Bylund A, Saarinen N, Zhang JX, Bergh A, Widmark A, Johansson A, Lundin E, Adlercreutz $H$, Hallmans G, Stattin P, Makela S. 2005. Anticancer effects of a plant lignan 7-hydroxymatairesinol on a prostate cancer model in vivo. Experimental Biol. Medicine. 230, 217-223.

Daun JK, Barthet VJ, Chornick TL, Dugiud S.2003. Structure, composition and variety development of flaxseed. Thompson I. U., Cannane, S.C. (Eds.), Flaxseed in Human Nutrition. AOCS Press. Champaign, USA, 1- 40.

Gao, M. and Liu, CZ. 2006. Dynamic microwave assisted extraction of flavonoids from Saussurea medusa maximum culture cells. J. Biochem. Eng. 32, 79-83.

Herchi W, Sawlha S, Arraez D, Boukhchina S, Carretero A, Kallel H, utierrezz AF. 2011. Determination of phenolic and other polar compounds in flax seed oil using liquid chromatography with time- of -flight mass spectrometry. Food Chem. 126, 332-338.

Hosseinian FS, Muir AD, Westcott ND, Krol ES. 2006. Antioxidant capacity of flaxseed lignans in two model systems. J. Am. Oil Chem. Soc. 83, 835-840.

Hussain S, Anjum FM, Alamri MS. 2011. Fortification of pan bread with healthy flaxseed. Aus. J. Basic. App. Sci. 5, 978-983.

International Standards Organization (ISO). Animal Feeding Stuffs -Determination of Nitrogen and Calculation of Crude Protein Content, ISO: Geneva, Switzerlanld, 1981; Standard 5983.

International Standards Organization (ISO). Oilseed Residues- Determination of Total Ash; ISO: Geneva, Switzerland, 1977; Standard 749.

IUPAC. Standard Methods for the Analysis of Oils, Fats and Derivatives, 7th revised Edn. International Union of Pure and Applied Chemistry, Blackwell Scientific, London 1987.

Kaufmann B, Christen P. 2002. Recent extraction techniques for natural products: microwave-assisted extraction and pressurised solvent extraction. Phytochem. Anal. 13, 105-113.

Kouba M. 2006. Effect of dietary omega-3 fatty acids on meat quality of pigs and poultry. In: MCT Eagle (ed). 
Omega 3 Fatty Acid Research. Nova Publishers. New York, USA, pp. 225-239

Latif S, Anwar F. 2011. Aqueous enzymatic sesame oil and protein extraction. Food Chem. 125, 679-684.

Latif S, Anwar F, Ashraf M. 2007. Characterization of enzyme-assisted cold pressed cotton seed oil. J. Food Lipids. 14, 424-436.

Latif S, Anwar F, Hussain AI, Shahid M. 2011. Aqueous enzymatic process for oil and protein extraction from Moringa oleifera seed, Eur. J. Lipid Sci. Technol. 11, 1012-1018

Latif S, Anwar F. (2009). Physico-chemical studies of hemp (Cannabis sativa) seed oil using enzymeassisted cold pressing. Eur. J. Lipid Sci. Technol. 10, 1042-1048.

Maillard V, Bougnoux $P$, Ferrari $P$, Jourdan ML, Pinault M, Lavillonniere F, Body G, Le Floch O, Chajes V. 2002. n-3 and n-6 fatty acids in breast adipose tissue and relative risk of breast cancer in a case-control study in Tours France. Int. J. Cancer. 98:78-83

Matthews KR, Homer DB, Thies F, Calder PC.2000. Effect of whole linseed (Linum usitatissimum $L$ ) in the diet of finishing pigs on growth performance and on the quality and fatty acid composition of various tissues. British J. Nutrition. 83, 637-643.

Mc Cann SE, Kulkarni S, Trevisan M, Vito D, Nie J, Edge SB, Muti P, Freundenheim JL. 2006. Dietary lignan intakes and risk of breast cancer by tumor estrogen receptor status. Breast Cancer Res. Treatment. 99, 309-311.

Min DB. 1983. Analyses of flavor qualities of vegetable oils by gas chromatography. J. Am. Oil Chem. Soc. 60, 544-545.

Moure A, Dominguez H, Zuniga ME, Carmen S, Chamy R. 2002. Characterization of protein concentrates from pressed cakes of Guevina avellana (Chilean hazelnut). Food Chem. 78, 179-186.

Oomah B D. 2001. Flaxseed as a functional food source. J. Agric. Food Chem. 81, 889-894.

Parry J, SU L, Luther M, Zhou K, Yurawecz MP, Whittaker $\mathrm{P}$, 2005. Fatty acid composition and antioxidant properties of cold-pressed marionberry, boysenberry, red raspberry, and blueberry seed oils. J. Agric. Food Chem. 53, 566-573.

Ranalli A, De Mattia G. 1997. Characterization of olive oil produced with a new enzyme processing aid. J. Am Oil Chem. Soc., 74, 1105-1113.
Ranalli A, Malfatti A, Lucera L, Contento S, Sotiriou E. 2005. Effects of processing techniques on the natural colorings and the other functional constituents in virgin olive oil. Food Res. Int. 38, 873-878.

Riley PA, Enser M, Nute GR , Wood JD. 2000. Effects of dietary linseed on nutritional value and other quality aspects of pig muscle and adipose tissue. Animal Sci. 71, 483-500.

Schaefer EJ. 2002. Lipoproteins, nutrition, and heart disease. Am. J Clin. Nutr. 75, 191-212

Siger A, Malgorzata NK, Eleonora LS. 2008. The content and antioxidant activity of phenolic compounds in cold-pressed plant oils. J. Food Lipids 15, 137-149.

Singh RK, Sarker BC, Kumbhar BK. 1999. Response surface analysis of enzyme assisted oil extraction factors for sesame, groundnut and sunflower seeds. J. Food Sci. Technol. 36, 511-514.

Soto CG, Chamy R, Zuniga M. 2004. Effect of enzymatic application on Borage (Borago officinalis) oil extraction by cold pressing. J. Chem. Eng. Japan. 37, 326-331.

Steel, F, Torrie GJH and Dickey DA. 1997. Principals and procedures of biometrical approach $3^{\text {rd }}$ edition. W. C. McGraw Hill, New York

Tarpila A, Wennberg T, Tarpila S, 2005. Flaxseed as a functional food. Curr. Top. Nutrac. Res. 3, 167-188.

Tzen JTC, Huang AHC. 1992. Surface structure and properties of plant seed oil bodies. J. of biological chem. 117, 327-335.

Westcott ND, Muir AD. 2003. Flaxseed lignan in disease prevention and health promotion. Phytochem. Rev. 2, 401-417.

Wrolstad RE. 2003 in: Wrolstad, R. E. (Ed.), Current Protocols in Food Analytical Chemistry (CPFA), John Wiley \& Sons, UK, pp. 6902-6904.

Yen GC, Duh PD, Chuang DY. 2000. Antioxidant activity of anthraquinones and anthrone. Food Chem. 70, 307-315.

Zuniga ME, Chamy R, Lema JM. 2001. Canola and Chilean hazelnut products obtained by enzymeassisted cold-pressed oil extraction. In Proceedings of the world conference and exhibition on oilseed processing and utilization (R.F. Wilson, ed.). AOCS Press, Champaign, pp. 210-213.

Recibido: $11 / 12 / 12$ Aceptado: $15 / 5 / 13$ 